\title{
PENGUATAN UMKM TEPUNG TAPIOKA BERBASIS SISTEM INFORMASI MANAJEMEN RANTAI PASOK RAMAH LINGKUNGAN
}

\author{
Daniel Alfa Puryono ${ }^{1}$, Listiarini Edy Sudiati ${ }^{2}$ \\ 1,2 Program Studi Sistem Informasi, STIMIK AKI Pati \\ e-mail: 1danielsempurna@gmail.com, ${ }^{2}$ listiarini@gmail.com
}

\begin{abstract}
ABSTRAK
Pengunaan dan pengelolaan sistem informasi di era globalisasi saat ini menjadi sangat penting untuk meningkatkan usaha mikro kecil dan menengah (UMKM) yang ramah lingkungan. Sehingga mau tidak mau pemilik usaha harus merancang dan mengunakan strategi yang efektif untuk pengelolaan sitem informasi rantai pasok yang ramah lingkungan. Karena UMKM dengan keterbatasan sumber daya belum sepenuhnya mampu untuk mengelola dan merasakan manfaat dari fungsi sistem informasi rantai pasok untuk kegiatan operasional meraka. Survei dilakukan pada 15 UMKM Tepung Tapioka Kabupaten Pati dan interview pada 5 responden dari praktisi (Bappeda, FEDEP dan Dewan Riset Daerah). Hasilnya masih banyak UMKM yang belum memanfaatkan sistem informasi untuk mengembangakan usaha mereka secara optimal. Selain itu ada beberapa masalah yang perlu di kelola dalam sistem informasi tersebut yaitu: rantai pasok yang ramah lingkungan, strategi sistem infomasi, manfaat dan hambatan penerapan sistem informasi serta nilai kompetitif dari UMKM. Penelitian ini bertujuan untuk mengidentifikasi dan mengelola indikator-indikator penting permasalahan tersebut. Sehingga hasilnya dapat menjadi rekomendasi bagi manajemen puncak atau pemilik usaha. Karena dapat memberikan informasi operasional lebih optimal baik secara internal maupun eksternal. Sehingga akan tercapai budaya kerja yang efektif khusunya pada UMKM Tepung Tapioka di Kabupaten Pati untuk dapat bersaing di pasar global.
\end{abstract}

Kata Kunci: SIM, UMKM, Rantai Pasok.GSCM

\section{PENDAHULUAN}

Saat ini perusahaan bahkan usaha mikro kecil dan menengah (UMKM) berlomba untuk meningkatkan daya saing organisasi mereka agar dapat bersaing di pasar global. Serta menjadi perusahaan yang fleksibel dan responsif terhadap kebutuhan pasar yang terus berubah. Manajemen rantai pasok didefinisikan sebagai integrasi kunci proses bisnis mulai dari pengguna akhir sampai ke pemasok yang menyediakan produk, layanan dan informasi. Sehingga mempunyai nilai tambah bagi pelanggan dan pemangku kepentingan lainnya [1]. Karena penyedia atau pemasok berada di beberapa tempat yang berbeda, sehingga penting untuk mengintegrasikan kegiatan baik di dalam maupun di luar perusahaan. Hal ini membutuhkan sistem informasi yang terintegrasi untuk berbagi informasi. Sampai saat ini manajemen sistem informasi yang efektif untuk meningkatkan proses rantai pasok yang ramah lingkungan belum mendapat perhatian yang cukup, khususnya untuk integrasi antara sistem informasi manajemen (SIM), rantai pasok ramah lingkungan atau green supply chain management (GSCM) dan UMKM.

Manajemen rantai pasokan yang berkelanjutan merupakan proses dari pengelolaan material, informasi, arus modal dan kerjasama di antara perusahaan rantai pasok serta aspek lingkungan. Karena hubungan antara aspek lingkungan dan manajemen perusahaan sangat penting untuk pelangan, pemasok dan pengambilan keputusan. Masalah yang perlu mendapat keprihatinan atas isu-isu pencemaran lingkungan adalah dengan menerapkan manajemen rantai pasok ramah yang lingkungan [2]. Jadi sangat penting suatu organisasi dapat memahami bagaimana mengintegrasikan sistem informasi dan praktik ramah lingkungan untuk meningkatkan kemampuan bisnis dan mengidentifikasi kinerja yang lebih baik.

Sistem informasi saat ini diangap sebagai alat utama yang bisa memberikan keunggulan kompetitif bagi perusahaan baik dalam rantai pasok barang maupun jasa [3]. Dengan adanya pengelolan sistem informasi yang baik diharapkan dapat membantu UMKM tepung tapioka agar bisa terintergasi antar mitra rantrai pasok dengan proses bisnis UMKM itu sendiri. Dalam perkembang bisnis yang dinamis saat ini, dimana pemanfaatan daur ulang limbah, pengembangan dan penyesuaian produk serta munculnya perangkat teknologi yang baru membuat pengelolan sistem informasi menjadi sangat penting untuk bisa bertahan dalam bisnis mapun kinerja UMKM.

Di Indonesia UMKM telah banyak menyumbang laju pertumbuhan perekonomian bahkan mengurangi jumlah pengangguran. Berdasarkan laporan BPS dari hasil sensus ekonomi (SE) tahun 2016 yang dirilis pada bulan Desember 2017. UMKM mendominasi unit bisnis di Indonesia dan mampu menyerap hampir $97 \%$ tenaga kerja Indonesia. Dari angka tersebut, jenis usaha mikro paling banyak menyerap tenaga kerja hingga $87 \%$. Sedangkan usaha besar hanya menyerap 3,3\% [4]. Meskipun begitu masih ada beberapa masalah yang dihadapi UMKM antara lain, sumber daya, dampak lingkungan, aset modal dan kondisi sosial masyarakat. Kendala ini antara lain ditimbulkan oleh peran lembaga pemberi pinjaman, sumber daya informasi yang tidak memadai, bencana alam, perubahan kondisi perekonomian, pemasaran, rantai pasok bahan baku yang tidak teratur. Bahkan sejak diterapkanya sistem perdanganan bebas membuat permasalahan semakin berkembang. Hal ini memaksa UMKM mau tidak mau harus mengunakan strategi bisnis modern. Supaya dapat memenui standat produk yang diinginkan pasar. Meskipun dinegara berkembang, pemerintah mempunyai pengaruh yang kuat atas industri atau 
UMKM untuk mengontrol sumber daya maupun mengatur harga jualnya [5]. Diera sekarang ini jelas bahwa kelangsungan UMKM akan ditentukan terutama oleh kemampuan mereka untuk memproduksi atau memberi pasokan yang maksimal dengan biaya yang lebih kopetitif serta pengiriman dalam waktu yang cepat, tepat serta minimum cacat dengan mengunanakan sumber daya yang relatif sedikit.

Bagaimana UMKM bisa mengatasi hal itu semua seiring dengan lingkungan bisnis yang berubah dengan cepat. Salah satu solosinya adalah dengan merancang sistem informasi manajemen yang efektif. agar UMKM bisa saling melengkapi antar unit usaha. Oleh karena itu, tujuan dari penelitian ini adalah untuk mengidentifikasi dan merencanakan penggunaan sistem informasi untuk mendukung manajemen rantai pasokan yang berkelanjutan. Serta mengidentifikasi isu-isu utama dalam penerapan sistem informasi manajemen dan rantai pasok ramah lingkungan. Penelitian ini bisa menjadi masukan yang berguna bagi administrasi organisasi, karena menyoroti manfaat penggunaan sistem informasi dalam praktik rantai pasokan yang berkelanjutan.

\section{TINJAUAN PUSTAKA}

\subsection{Sistem Informasi Dalam Manajemen Rantai Pasokan Ramah Lingkungan}

Konsep desain manajemen rantai pasokan ramah lingkungan telah menjadi penelitian yang semakin berkembang. Hal ini seiring dengan perkembangan teknologi informasi dan komunikasi (TIK) yang mencakup pengolahan data elektronik, pengunaan internet serta website. Manajemen rantai pasok menekankan manfaat jangka panjang dari semua pihak pada rantai pasok melalui kerjasama dan berbagi informasi. Hal ini menandakan pentingnya komunikasi dan penerapan sistem informasi manajemen rantai pasokan [1]. Karena permasalahan yang sering terjadi adalah kurangnya integrasi antara sistem informasi dan model bisnis rantai pasok. Antara lain kurangnya perencanaan strategis yang tepat, infrastruktur TI yang buruk, aplikasi sistem informasi yang tidak memadai di UMKM dan implementasi tentang sistem informasi manajemen rantai pasokan. Beberapa penelitian sebelumya tentang sistem informasi manajemen rantai pasok masih berfokus pada strategi perencanaan dengan tujuan pengembangaan rencana jangka panjang dan perubahan organisasi sehingga dapat meningkatkan daya saing. Sedangkan dalam strategi perencanaan membutuhkan keterlibatan manajemen puncak agar mempertimbangkan faktor eksternal maupun internal.

Pentingnya pemahaman tentang proses bisnis dan cara kerja sistem informasi yang cocok untuk manajemen rantai pasok. Membutuhkan komitmen pemelik usaha untuk proses organisasi di masa depan. Karena inovasi bukan hanya proses teknis atau hanya untuk bisa memecahkan masalah saja tetapi juga melibatkan proses ekonomi dan mengaktualisasi kepentingan politik. Selain itu kondisi pasar juga merupakan kekuatan pendorong untuk setiap perubahan dalam sebuah organisasi. Faktor pasar seperti kebutuhan pelangan, pesaing, harga dan kualitas. Dengan demikian sistem informasi menjadi penting sebagai sumber informasi yang handal dan terpercaya untuk mendukung dalam pengambilan keputusan. Peran sistem informasi manajemen rantai pasokan telah banyak dibahas. Beberapa peneliti berpendapat bahwa tidak mungkin dapat mencapai rantai pasokan yang efektif tanpa perangkat sistem informasi [1]. Bahkan sistem informasi telah diidentifikasi sebagai faktor kunci untuk mencapai kelestarian lingkungan [6,7,8]. Mereka memfasilitasi penyelarasan perencanaan informasi dan keberlanjutan dengan praktik organisasi ramah lingkunga. Sistem informasi dapat menjadi sebuah sistem untuk proses berkelanjutan, layanan dan produk. Karena kemampuan sistem informasi mampu untuk meningkatkan komunikasi dan berbagi pengetahuan untuk seluruh fungsi dengan persyaratan lingkungan yang efektif [9].

\subsection{Peran Teknologi Informasi dan Sistem Informasi Manajemen}

Teknologi informasi (TI) didefenisikan dalam atri luas sebagai perangkat teknologi yang didedikasikan untuk penyimpanan informasi, pengelolaan dan komunikasi. Sedangkan perangkat TI merupakan kombinasi dari hadware, software, telekomunikasi dan peralatan perkantor yang mengubah data mentah menjadi informasi untuk pengambilan keputusan secara cepat [10]. Banyak penelitian terdahulu yang mengamati pengelolaan TI ternyata memiliki hubungan yang positif dengan pengelolan sistem informasi. TI diangap sebagai salah satu sumber daya strategis untuk memperoleh keungulan melalui peningkatan kinerja. Bahkan menurut sharma dan bhagwat [5] pengunaan internet dalam UMKM sebagai bagian dari sistem informasi manajemen menemukan bahwa meskipun pengunaan e-mail sangat popular untuk komunikasi bisnis dan mengirim dokumen. Tetapi belum ada integrasi antara internet dengan aplikasi perkantoran yang digunakan.

Jadi penelitian ini merekomendasikan kepada pemilik perusahaan supaya tidak hanya membeli teknologi terbaru saja. Tetapi juga mendorong agar mereka bisa mengarahkan kepada karyawan untuk belajar dan mengunakan berbagai teknik telemarketing, mendukung operasional internal dan fungsi bisnis eksternal. Sehingga mendapatkan keuntungan bisnis dan bisa membangun budaya pengunaan sistem informasi. Jadi untuk mencapai hal ini diperlukan strategi sistem informasi yang tepat untuk diterapkan dalam sebuah industri. Banyak faktor yang mempengarui keungulan sistem informasi untuk penguatan UMKM. Salah satu manfaatnya adalah bisa menjadi motivasi untuk pemilik usaha maupun organisasi. Karena bisa membantu menyelesaikan beberapa hambatan antara lain tentang keterampilan akan sistem informasi, kurangnya waktu yang dimiliki, kurangnya dana dan beberapa kendala teknis lainya seperti kemampuan pengunaan perangkat keras maupun perangkat lunak. 


\subsection{Usaha Mikro Kecil Dan Menengah (UMKM)}

UMKM umumnya berada dalam satu klaster. Karena ada beberapa alasan antara lain : ketersediaan bahan baku, tenaga kerja, warisan atau budaya lokal serta fasilitas tranportasi. Sedangkan definisi UMKM berbeda antar negara yang satu dengan yang lain. Begitu juga dengan dasar yang digunakan antara jumlah karyawan dan modal invesatsi yang digunakan. Tabel 1. dibawaah ini menujukan perbedaan definisi UMKM antar negara menurut Bhagwat dan Sharma [3].

Tabel 1. Definisi UMKM Di Beberapa Negara.

\begin{tabular}{|l|l|l|}
\hline Negara & Kategori & Kriteria \\
\hline Indonesia & UMKM & $<100$ karyawan \\
\hline Malaysia & IKM & $<175$ Pekerja dan Investasi US\$ 1 Juta \\
\hline Thailand & Padat Karya & $<100$ Karyawan \\
\hline Australia & Jasa & $<20$ Karyawan \\
\hline Jerman & UKM & $<500$ Karyawan \\
\hline Perancis & UMK & $10-499$ Karyawan \\
\hline Jepang & Pabrik & $<200$ Karyawan \\
\hline Kanada & Pabrik & $<200$ Karyawan \\
\hline Cina & UMK & $<100$ karyawan dan investasi US\$ 8 Juta \\
\hline Amerika Serikat & Sangat kecil & $<20$ Karyawan \\
& Kecil & 20-99 Karyawan \\
& Menegah & $100-499$ Karyawan \\
\hline
\end{tabular}

Selain definisi diatas UMKM juga mempunyai karakteristik sebagai berikut :

a. Manajemen masih bersifat perorangan dengan otoritas yang terbatas.

b. Keterbatasan sumber daya dalam mengelola tenaga kerja, keuangan dan pemasaran.

c. Masih bersifat informal dan strateginya sering berubah ubah.

d. Memiliki potensi inovasi yang tinggi.

e. Masih tergantung pada sejumlah kecil pelangan serta pasar yang terbatas.

f. Kapasitas investasi keuangan masih terbatas

Sedangkan salah satu ciri yang membedakan antara UMKM dengan perusahaan besar adalah jenis informasi dan persyaratan sistem informasi yang diterapkan. Karena sifat perusahaan skala besar menuntut informasi dengan cara yang lebih sistematis dan terorganisir dari pada UMKM. Perusahaan skala besar, sumber daya dimanfaatkan untuk memenuhi kebutuhan informasi. Meskipun perusahaan skala besar mampu untuk investasi yang lebih dalam pengelolaan sumber daya informasi untuk mendapat keuntungan dari sekecil apapun informasi untuk membantu dalam meningkatkan nilai bisnis, maupun jejaring bisnis. Sedangkan UMKM belum memiliki infrastruktur dan sumber daya untuk mendapat informasi yang diperlukan terkait dengan bisnis yang dijalankan mereka. Sehingga daya saing mereka lemah dan sering menderita kerugian dalam berbisnis.

\section{METODE PENELITIAN}

Target penelitian ini pada UMKM tepung tapioka yang berada di Kecamatan Margoyoso Kabupaten Pati. Jumlah sampel yang diambil 15 industri dari Desa Ngemplak kidul, Waturoyo, Sidomukti dan Tanjungrejo. Selain itu juga mewawancarai 5 responden dari praktisi. Karena tempat penelitian ini terdapat dibeberapa UMKM yang tersebar di Kecamatan Margoyoso, maka penelitian ini mengunakan metodologi survei cross-section serta didasarkan pada kuesioner dan wawancara secara pribadi kepada pemilik UMKM, perwakilan Bappeda, FEDEP dan Dewan Riset Daerah Kabupaten Pati.

\section{HASIL DAN PEMBAHASAN}

Pada era industri 4.0 saat ini dan seterusnya perangakat teknlogi maupun sistem infomasi akan terus merevolusi industri, organisasi maupun kumunikasi di dunia. Tanpa memperhatikan lokasi goegrafis mereka. Tidak hanya melintasi batasan-batasan fungsional antar depertemen atau manajemen tetapi juga melintasi batasbatas organisasi. Dengan demikian manajemen sistem informasi dapat memberikan pengaruh yang cukup besar dalam operasi bisnis untuk UMKM. Karena di era sekarang ini kelangsungan UMKM akan ditentukan oleh kemampuan dalam memproduksi serta memberikan yang lebih untuk rantai pasok dengan biaya yang kompetitif serta minimalis sumber daya yang digunakan.

Dari hasil analisa pengolahan data sementara pada industri tepung tapioka ini rata-rata belum ada yang memanfaatkan perangkat teknologi informasi (TI) atau mengunakan sistem informasi untuk keperluan organisasi bisnis mereka secara efesien. Hasil survei untuk pengunaan perangkat TI. Menunjukan bahwa jumlah komputer yang digunakan memang sudah cukup memadai karena $73 \%$ dari UMKM telah mengunakan lebih dari 3 komputer, sedangkan 27\% mengunakan 1 komputer. Namun pengunaan komputer masih terbatas pada pemilik usaha saja. Serta pemanfaatan komputer baru sebatas untuk email dan komunikasi sosial. Belum digunakan untuk perkantoran, marketing serta jual beli online. Maka dari hasil diatas menunjukan bahawa UMKM memerlukan perangkat sistem informasi dan aplikasi yang efektif dan ramah lingkungan. 
Dengan pengelolaan sistem informasi, UMKM dapat mengintegrasikan operasi manufaktur dengan proses bisnis yang lainya. Meningkatkan nilai tambah rantai pasok, serta dapat mempercepat dan membuat koordinasi yang tepat antar berbagai mitra rantai pasok. Jadi strategi sistem informasi harus mencakup tujuan dari strategi manajemen rantai pasok itu sendiri. Sehingga keselarasan antara model informasi dan model rantai pasokan akan berjalan dengan efektif. Sehingga sistem informasi manajemen yang diusulkan akan sangat membantu untuk peningkatan kinerja rantai pasok bagi UMKM.

\subsection{Manfaat Sistem Informasi Pada Manajemen Rantai Pasok Ramah Lingkungan}

Ada beberapa manfaat yang bisa dirasakan dalam penerapan sistem informasi manajemen rantai pasok. Aplikasi berbasis sistem informasi dapat meningkatkan pelayanan serta membantu UMKM untuk lebih fokus pada kebutuhan pelangan melalui interaksi langsung dengan mereka. Baik tentang status pesanan mereka, ketersediaan persediaan, informasi proses produk, pergudangan maupun pengiriman tanpa harus menunda respon dengan mereka karena tersedianya basis data dalam sistem, sehingga pelangan akan merasa puas. Selain itu UMKM akan lebih kompetitif karena waktu pengiriman barang akan lebih cepat, hubungan bisnis dengan mitra rantai pasok lebih baik, produk-produk lebih inovatif dan berkwalitas, biaya menjadi lebih murah. Serta dapat meningkatkan citra perusahaan dan merek dan mengurangi jumlah dokumen dalam berbentuk kertas. Sedangkan manfaat untuk pengelolaan organisasi pada UMKM diantaranya:

1. Sistem pengambilan keputusan : membantu UMKM dalam pengambilan keputusan bisnis yang penting dan strategis seperti investasi dan peluncuran produk baru.

2. Operasional : dapat membantu UMKM dalam memberikan informasi pada setiap langkah operasional. Baik perkembangan terbaru tentang teknologi yang digunakan, produk, keinginan pelangan dan perkiraan pasar.

3. Komunikasi : komunikasi antar UMKM dengan pemasok, pelangan (semua rantai pasok) bisa ditingkatkan.

4. Koordinasi antar UMKM : selain berhubungan dengan pemasok dan pelangan UMKM akan dapat berbagi pengalaman dengan UMKM lainya tentang produk, proses bisnis, pelangan, pemasok dan hal-hal lain yang menyangkut kepentingan bersama.

5. Pemasaran : sistem informasi dapat mengatasi batasan batasan goegrafis, untuk malakukan pemasaran secara global dengan biaya yang terjangkau.

\subsection{Hambatan Sistem Informasi Pada Manajemen Rantai Pasok Ramah Lingkungan}

Selain manfaat yang sudah dijelaskan di atas ada juga beberapa hambatan dalam penerapan sistem informasi pada manajemen rantai pasok ramah lingkungan antara lain.

1. Jika visi misi perusahaan belum mangarah kepada penerapan pengunaan sistem informasi

2. Adanya ancaman keamanan akan informasi

3. Ketakutan akan sistem informasi yang tidak stabil

4. Fasilitas serta infrastruktur komputer yang buruk

5. Kurangnya pelatihan serta motivasi dari pengunan sistem informasi dan perangkat TI

6. Terpengaruh terhadap perubahaan dan ingin mengunakan perangkat TI yang selalu baru.

Sehingga untuk mengatasi hal tersebut pemilih usaha atau UMKM harus memahami sistem informasi dalam organisasi. Yaitu bagaimana sistem informasi dilaksanakan. Bagaimana sistem informasi berhubungan dengan manajemen operasional. Siapa yang bertangung jawab untuk penerapan SIM pada UMKM agar efektif.

\subsection{Kerangka Sistem Informasi Manajemen}

Kerangka sistem informasi manajemen untuk mengembangkan dan mengelola rantai pasok ramah lingkungan yang efektif sebagai berikut :

1. Perancangan strategi sistem informasi manajemen, mempunyai tugas yang sangat penting agar manajemen rantai pasok dilengkapi sistem informasi. Hal ini memiliki implikasi jangka panjang pada kinerja SIM pada GSCM. Strategi ini mencakup partisipasi manajemen, rencana bisnis jangka panjang, pasar global, daya saing, virtual enterprise, mudah meyesuaikan, biaya, E-bisnis, strategi kemitraan, Marger, akuisisi, produk baru atau jasa, reputasi, intergrasi sistem.

2. Pelaksanaan sistem informasi manajemen, mencakup dukungan dari manajemen puncak, tim proyek dengan kemampuan TI, rekayasa proses bisnis, SDLC, dukungan keuangan, pemberdayaan karyawan, matrik pengeukuran kinerja.

3. Pendidikan dan manajemen sistem informasi, mencakup pendidikan dan pelatihan TI, pelatihan kompetensi inti, modal pengetahuan, E-learning, multimedia, skema insentif, pemberdayaan tim kerja.

4. Infrastruktur meliputi perencanaan sumber daya perusahaan, pembaruan untuk proses bisnis, konektifitas internet, investasi TI, ketersediaan software dan hardware, platform e-commerce, XML, LAN, MAN, WAN, internet, keterampilan TI, evaluasi TI. Karena perusahaan akan banyak mengalami kerugian tanpa memiliki cukup pengetahuan tentang apa jenis infrastruktur TI atau sistem yang diperlukan untuk model bisnis rantai pasok yang mendukung sistem informasi manajemen.

5. E-Commerce mencakup persaingan dan pasar global, perusahaan digital, akses alternatif ke pasar, membuka jaringan baru, kemajuan teknologi, meningkatkan strategi dengan mitra, pengurangan biaya, komunikasi yang terbuka, peningkatan kerjasama tim, meningkatkan hubungan pelangan dengan manajemen. Jadi dengan 
perkembangan teknologi berbasis Internet, integrasi e-commerce dengan GSCM menjadi suatu keharusan. Karena hal ini bisa mendukung berbagai kegiatan di dalam rantai pasok.

6. Virtual Enterprise yang didasarkan pada pemanfaatan kompetensi inti dengan tujuan menjadi fleksibel dan responsive dalam mengubah kebutuhan pasar. Perusahaan akan berintegrasi dengan berbagai mata rantai pasokan dan mendukung sistem informasi yang digerakkan oleh kebutuhan untuk merampingkan operasi. Hal ini mencakup kemitraan berdasarkan kompetensi, kolaborasi jaringan, Tim virtual, manufaktur virtual, rantai pasok, sistem perencanaan sumber daya perusahaan, e-commerce termasuk B2B, B2C, pendidikan dan pelatihan teknologi informasi.

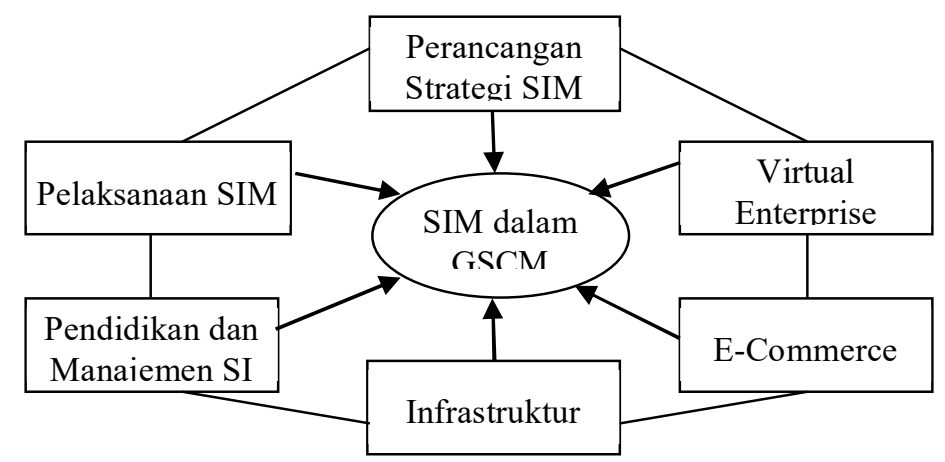

Gambar 1. Kerangka Kerja Pengembangan Sistem Informasi Untuk Efektifitas GSCM

Seperti pada gambar 1 diatas peran manajemen puncak sangat penting dalam membuat keputusan yang strategis khususnya sistem informasi manajemen agar efektif dalam penerapan GSCM. Hal ini tidak hanya berhubungan dengan sebuah software saja tetapi beberapa proses bisnis, investasi dan cara perusahaan beroperasi.

\section{KESIMPULAN}

Dengan memanfaatkan kemajuan teknologi informasi untuk meningkatkan produktifitas. Serta sistem informasi manajemen yang tepat tidak hanya membantu dalam komunikasi yang lebih cepat dan lebih luas tetapi juga dapat membantu UMKM dalam meningkatkan fungsi bisnis internal dan eksternal mereka. Seperti teknik dan desain aplikasi yang baik, produksi, peningkatan kualitas, pengelolaan bahan, respon yang cepat, pangsa pasar yang meningkat serta penerapan strategi bisnis yang tepat. Manajemen sistem informasi rantai pasok ramah lingkungan harus aksesibilitas, kompatibelitas, userfrendly, stabil dan handal. Selain itu pendidikan dan pelatihan adalah komponen paling penting dari setiap proses perubahan dalam suatu organisasi. Karena teknologi saja tidak akan membantu untuk meningkatkan daya saing UMKM. Karena untuk menerapkan sistem informasi manajemen yang berkelanjutan, tenaga kerja perlu termotivasi, beradaptasi sehingga siap menjalankan sistem informasi.

\section{SARAN}

Beberapa saran dalam penelitian ini adalah studi kasus masih satu jenis UMKM yang sama, serta lokasi yang hanya satu Kecamatan. Jadi perlu pengumpulan data dari dokumen UMKM yang ada, tidak hanya sebatas observasi, wawancara dan menyebar kuesioner saja. Sedangkan saran agar sistem informasi manajemen rantai pasok efektif dan berkelanjutan bagi UMKM maka diperlukan:

1. Dukungan manajemen puncak dan keterlibatan dalam pelaksanaan strategi sistem informasi akan sangat berkontribusi. Sehingga sistem informasi manajemen rantai pasok menjadi efektif bagi UMKM.

2. Melakukan invetasi teknologi informasi lewat berbagi data, internet, intranet, website, media sosial sehingga meningkatkan produktifitas operasional perusahaan bahkan memungkinkan pengambilan keputusan organisasi bisa secara cepat.

3. Peningkatan kinerja bisnis rantai pasok secara keseluruhan dengan mengintegrasikan antara pemasok, pelangan dan perusahaan sistem informasi.

\section{UCAPAN TERIMA KASIH}

Penulis mengucapkan terima kasih kepada Direktorat Riset dan Pengabdian Masyarakat Direktorat Jenderal Penguatan Riset dan Pengembangan, Kementerian RISTEKDIKTI. Karena makalah ini merupakan hasil dari Penelitian Dosen Pemula (PDP) yang dibiayai KemenRistekDikti pada Tahun Anggaran 2018.

\section{DAFTAR PUSTAKA}

[1] Gunasekaran, A. and Ngai, E.W.T., 2004, Information Systems in Supply Chain Integration and Management, European Journal of Operational Research, 159(159), pp.269-295.

[2] Puryono, D.A. and Kurniawan, S.Y., 2017, Pengukuran Tingkat Efektivitas Kinerja UMKM Batik Bakaran Secara Berkelanjutan Mengunakan Model, Jurnal Informatika UPGRIS, 3(1), pp.16-23.

[3] Bhagwat, R. and Sharma, M.K., 2007, Information System Architecture : a framework for a cluster of small- 
and medium-sized enterprises ( SMEs ), Production Planning \& Control, 18(4), pp.283-296.

[4] Suhariyanto, 2017, Laporan Kinerja Badan Pusat Statistik Tahun 2016.

[5] Bhagwat, R., and Sharma, M.K., 2006, Management of Information System in Indian SMEs : an exploratory study, Enterprise Network Management, 1(1), pp.99-125.

[6] Bengtsson, F., and Agerfalk, P. J., 2011, Information Technology As a Change Actant Insustainability Innovation: Insights from Uppsala, The Journal of Strategic Information Systems, 20(1), 96-112.

[7] Elliot, S., 2011, Transdisciplinary Perspectives On Environmental Sustainability: Aresource base and framework for IT-enabled business transformation, MIS Quarterly, 35(1), 197-236.

[8] Wang, Y., Chen, Y., and Benitez-Amado, J., 2015, How Information Technology Influences Environmental Performance: Empirical Evidence From China, International Journal of Information Management, 35(2), $160-170$.

[9] Seidel, S., Recker, J., and Vom Brocke, J., 2013, Sensemaking and Sustainable Practicing: Functional affordances of information systems in green transformations, MIS Quarterly, 37(4), 1275-1299.

[10] Seyal, A., Rahim, M., and Rahim, N., 2000, An empirical investigation of the use of information technology among small and medium business organizations: a Bruneian scenario, The Electronic Journal of Information Systems in Developing Countries, Vol. 2, No. 7, pp.1-17. 